\title{
Congratulations Abid Moo Cruz, and Thank You
}

$\mathrm{O}$ ur youth are the future, and this is as true for the Society for Range Management, as it is for any organization. With this in mind, the Bureau of Land Management (BLM) has been proud to sponsor the award for 1st place in the SRM plant identification contest. In addition to a plaque, the winner of the contest is awarded a trip to Washington, DC. Abid Francisco Moo Cruz, a student from Universidad Autonoma Agraria Antonio Narro in Mexico, has won the plant identification contest each of the past 3 years, and his accomplishments deserve our recognition. Those of us involved in the management of rangelands always admire those rare individuals who can identify almost every plant they see, but Abid has an ability to identify range plants that has most of his fellow range specialists and researchers green with envy.

The plant identification contest grew out of an informal range plant contest that was held during the annual meeting of SRM in 1951, and the contest has been held during each of the annual meetings since that time. Abid has had the best performance in the history of SRM's plant identification contest. In his 1st attempt in 2001, Abid finished with a score of 932 points, which was good enough for 2nd place behind the winner, Mae Elsinger of the University of Alberta, who had 965 points. In 2002-2004, Abid finished in 1st place with scores of 953,973 , and 942 , respectively. Over that same period, the students finishing in 2nd place were also from Antonio Narro University. In 2002, Abid barely edged out Julian Cerano Paredes, who finished with 952 points. In 2003, Edgar G. De Anda Villarreal finished in 2nd with 938 points, and in 2004 Damian Gaytan Quiroz finished 2nd with 929 points. Although Abid Moo Cruz is recognized as the current record holder in this event, he was not the 1 st student to win the contest 3 times. Another student from Antonio Narro University, Guillermo Lopez Guillen, won 3 consecutive years, but Guillermo placed 12th in his 1st attempt.

When Abid first won this contest in 2002, he was given a trip to Washington, DC, which was Abid's 1st opportunity to visit the US Capitol. During this trip he was able to meet the BLM's director, Kathleen Clarke, and learn more about the BLM as well as other federal agencies involved with managing natural resources and agriculture (Photo 1). This allowed Abid to make comparisons with how similar resources are managed in Mexico. In addition to his official appointments, Abid also had the opportunity to visit most of the Smithsonian museums and other attractions in Washington. The Museum of Air and Space and the Botanical Garden were his favorites. He saw many of the memorials in the city and indicated that the Lincoln Memorial, with its view of the mall, was one of the highlights of that trip.

Since Abid had already been to Washington, DC, he was given a tour of the Pacific Northwest after he won the contest again in 2003. During this trip, Abid visited the Oregon capitol building in Salem, where he heard about the history of the state. Abid later toured the Range Management and Wildlife Departments at Oregon State University. During his trip, he visited the Yaquina Head Lighthouse managed by BLM and learned about the sea life in the tide area.

Touring the Olympic Peninsula was definitely a highlight of Abid's trip to the Pacific Northwest.

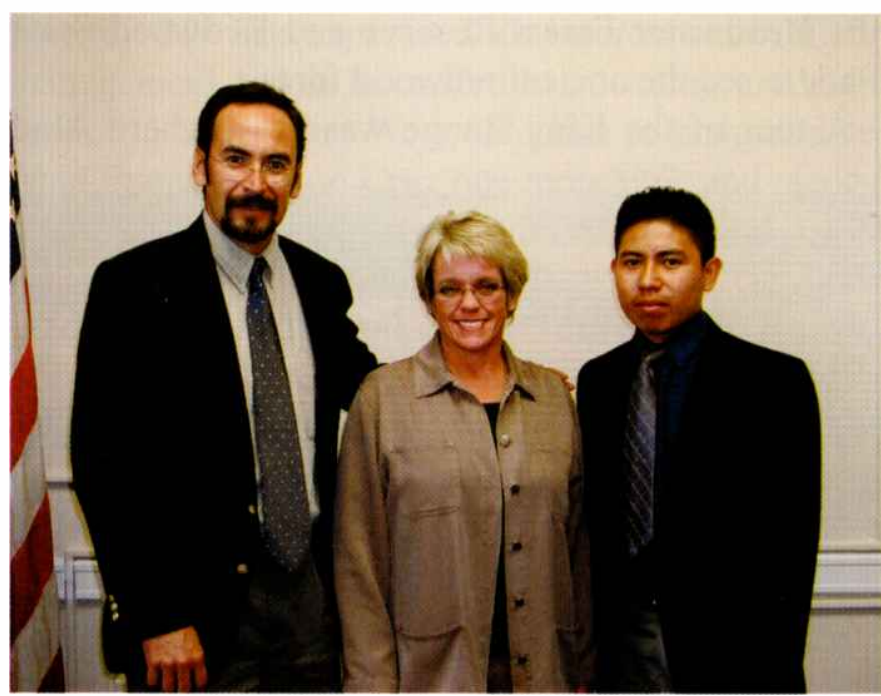

Dr Juan Manuel Martinez Reyna, BLM Director Kathleen Clarke, and Abid Francisco Moo Cruz. 


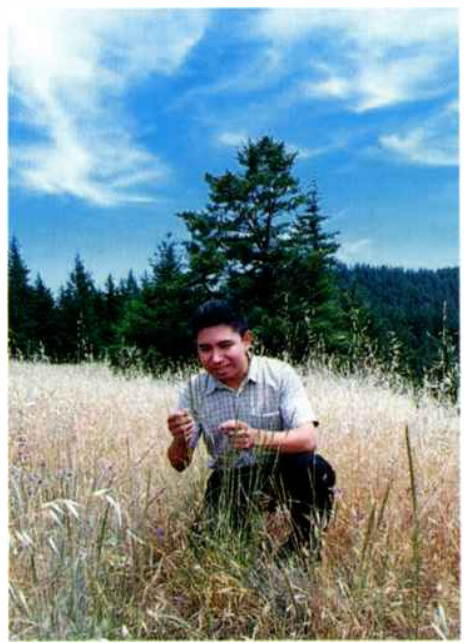

Abid examining Achnatherum.
Although he was very impressed with this entire area, Abid considered the Hoh Rain Forest as a favorite part of this trip. Later he reached Cape Flattery in the Makah Indian Reservation. From that point he saw whales and sea lions and, in the distance, Vancouver Island. He also visited the reservation's museum and learned about the tribe's culture and respect for Mother Nature. This trip would have been incomplete without seeing the Crescent Lake area with its waterfalls and the beautiful panoramic view of the Olympic Mountains from Hurricane Ridge. Abid also learned how nature rebuilds itself during his trip to Mount St. Helens National Volcanic Monument.

When Abid won the contest again in 2004, he was given a tour of northern California. He visited BLM's Arcata Field Office and Humboldt State University before the ecological tour began. $\mathrm{He}$ viewed a restoration project in Manila Dunes, an area of critical environmental concern, where he learned about BLM's efforts to reestablish the native vegetation community. After that, he traveled to the Headwater Forest Reserve and Redwood State Park to see the ancient redwood forests.

A tour of the King Range was next, where Abid

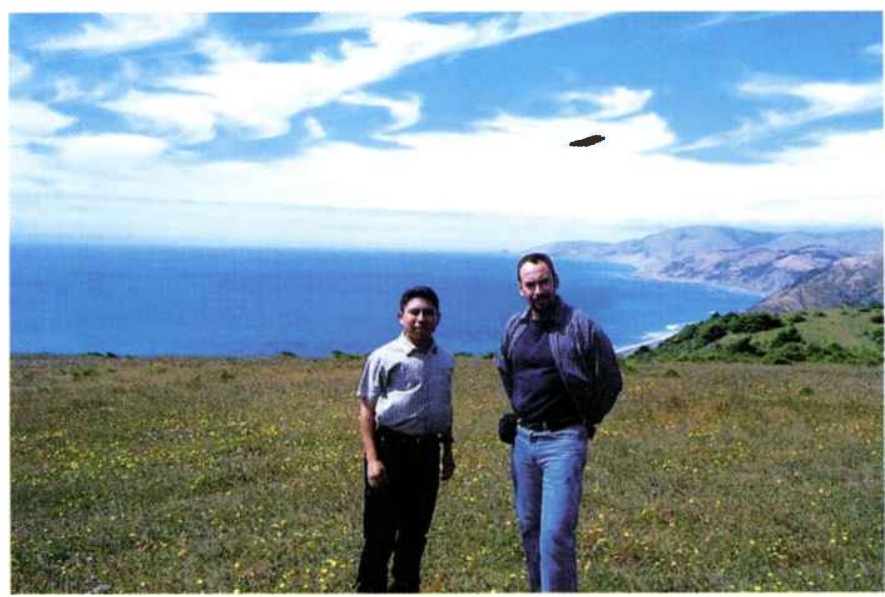

Abid and Dr Martinez on Strawberry Rock allotment. saw some of the native perennial bunchgrasses that he recognized from the master list of the SRM Plant Contest but had never actually seen alive and growing before (Photo 2). Efforts to preserve some of these native grasses because of risks caused by introduced annual species were described. He also visited 2 BLM grazing allotments, Strawberry Rock and Windy Point, where he collected some grasses for the Plant ID Team (Photo 3).

Later on this tour he was shown a successful weed management project and a granitic sedimentation dam to protect fish in Trinity River. During the visit to California, he had the opportunity to see a bald eagle nest with a young eagle and to see Mount Shasta, where he learned about the geology of the region where the Cascades Range begins.

On these trips, Abid was accompanied by his professor and plant identification team coach Dr Juan Manuel Martinez Reyna, who served as an interpreter (Photo 4). It is appropriate that we acknowledge his efforts and the accomplishments of the University of Antonio Narro as well. The Plant Identification team from Universidad Autonoma Agraria Antonio Narro has participated in all but 2 contests since 1976, and they have placed in the top 3 during every single contest they entered since 1983 (Photo 5). The team has been 1 st 15 times in the past 19 years and has never placed lower than 2nd in any contest they competed in since they first won in 1986. This included a string of 6 consecutive 1st-place finishes from 1988 through 1993 and a similar stretch from 1994 through 2000 that was interrupted only because they did not attend the 1999 meeting. The only comparable streak would be that

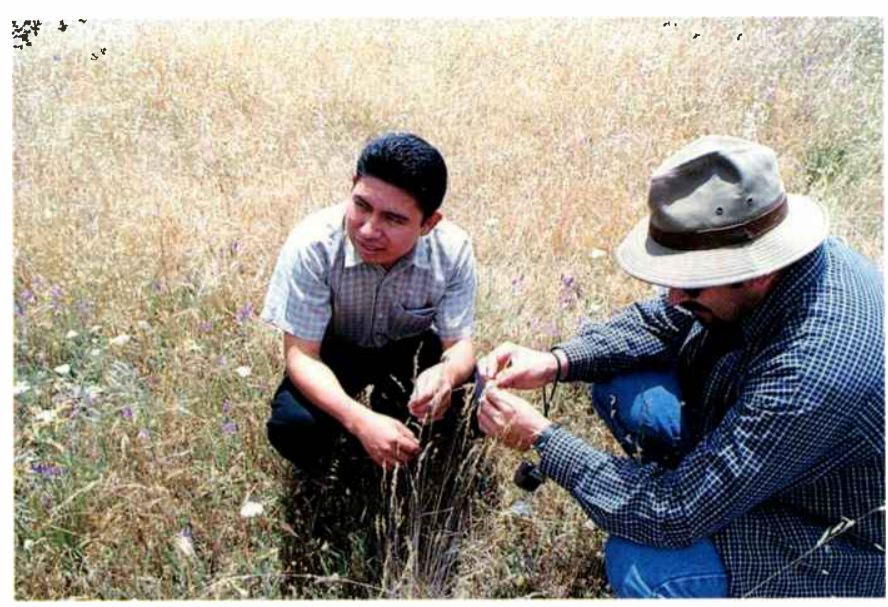

Abid and Dr Martinez examining range plants. 
of Texas Tech, when they finished 1st 6 consecutive years between 1965 and 1970 and finished 1 st 10 times between 1965 and 1978. As an undergraduate at Antonio Narro University, Dr Juan Manuel Martinez Reyna was a member of the plant identification team from 1983 through 1985. Dr Martinez has been coaching the Antonio Narro University plant team since 2000, and he again has his team working on a streak of 3 straight 1st-place finishes.

The accomplishments of the University of Antonio Narro, and specifically of Abid Moo Cruz, "raise the bar" for our student contests and cause all our students to try harder and study longer. These contests can only strengthen our range graduates and our society in the long run, and it is for this reason that a valuable prize such as a trip is appropriate. Although a prize cannot be awarded for each participant, we want to thank all the students and teams that put forth the time and effort to participate in these contests at the SRM annual meetings. These contests are an important part of those meetings, and the time and effort invested by each team member, as well as the team coaches, is appreciated.

Abid thanked the BLM for the 3 trips the agency sponsored, saying the experience gained on these trips has helped him learn how natural resources must be managed to preserve them for future generations. Although many BLM employees participated in portions of these trips, Dick Mayberry coordinated the trip to Washington, DC; Hugh Barrett was primarily responsible for the trip to the Pacific Northwest; and Jennifer Wheeler made the arrangements and introduced Abid to northern California. We certainly hope that Abid enjoyed the trips he took as the plant identification contest winner, and we hope those experiences will be helpful to him in the future. But the BLM and the Society for Range Management would also like to thank Abid. The individuals that took Abid on these trips enjoyed their time spent with him. They remember with fondness his reactions to holding a 25 -pound salmon and seeing the redwood forests for the 1 st time. They talk about his excitement at seeing alive and growing, some of the range plants he had only seen previously as preserved specimens in preparation for the contest. They refer to Abid as a very special young man and talk of being proud of his accomplishments.

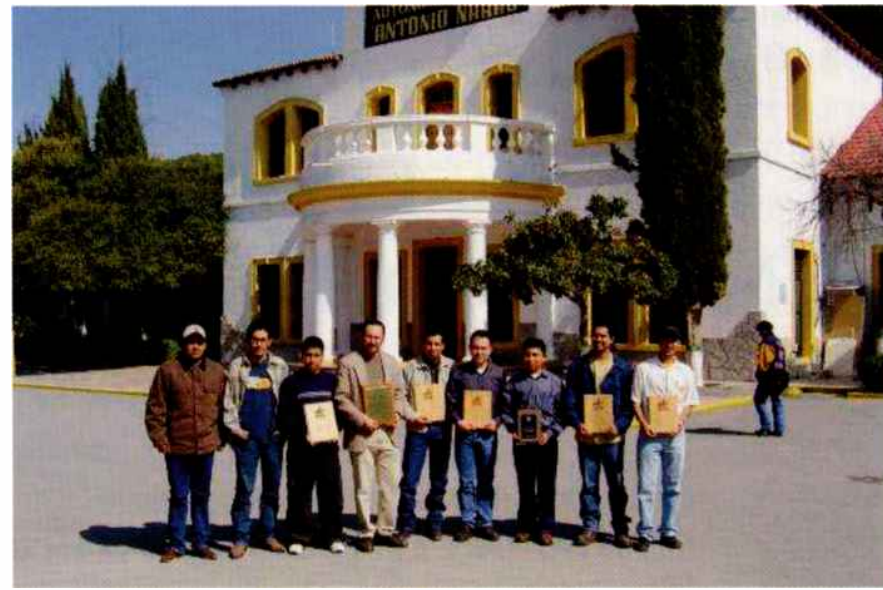

Universidad Autonoma Agraria Antonio Narro, Range Plant Identification Team.

The Society for Range Management spends a lot of time and effort reflecting on our past. It is appropriate that we reflect on our history, and we do so with great pride. But perhaps we have the luxury to spend such effort on our past because we know we have dedicated students such as Abid and the other participants in our range contests that represent our future. Like many range specialists, Abid was raised on a farm. He has now graduated from the Universidad Autonoma Agraria Antonio Narro and is currently spending 2 months in British Columbia, where he is working on improving his English and collaborating with their University College of Caribou plant identification team. Abid will then return to Campeche, Mexico, where he will work for the Agricultural and Livestock State Government Agency. He has expressed an interest in wildlife management and is interested in attending graduate school in the future. We would like to congratulate Abid Francisco Moo Cruz one more time and recognize him for his hard work, dedication, and a job well done. His accomplishments were not easy, his efforts that help make the Society for Range Management stronger are appreciated, and we wish him the best of luck in the future. Muy bien hecho y muchas gracias.

Editor's Note: Contributed by Doug Powell, rangeland management specialist, USDI-BLM Liaison, Society for Range Management, 445 Union Blvd, Suite 230, Lakewood, Colorado 80228. 